\title{
Syntactic Alternations of Hindi Verbs with Reference to the Morphological Paradigm
}

\author{
Debasri Chakrabarti
}

\author{
Department of Computer Science and \\ Engineering, Indian Institute of \\ Technology, Bombay Powai, Mumbai- \\ 400076 Indiadebasri@cse.iitb.ac.in
}

\author{
Pushpak Bhattacharyya \\ Department of Computer Science and \\ Engineering, Indian Institute of \\ Technology, Bombay Powai, Mumbai- \\ 400076 India pb@cse.iitb.ac.in
}

Keywords: Syntactic Alternation, Morphological Paradigm, Semantic Category.

\begin{abstract}
The aim of this paper is to show the alternation pattern of verbs in Hindi. The work is guided by Beth Levin's work on English verb classes and alternations where English verbs are classified semantically according to their argument structure [1]. There is a strong belief that the semantic nature of verbs is largely dependent on its argument structure. The nature of the Hindi verbs shows that along with the argument structure, attention should also be paid to the phonological changes which influence the morphological paradigms. Preliminary attempts have been made to class the simple verbs of Hindi into different morphological paradigms along with the phonological changes. At present, the work is limited only to the syntactic structure. Semantic characteristics have not been dealt with. Focus is mainly given on nominal, transitive-causative, and intransitive-causative variants.
\end{abstract}

\section{Introduction}

Verbs are the most important categories in parts of speech due to their distinctive behavior. It is the verbs that form the pivot of the sentence. A sentence without a verb is unthinkable. The knowledge of a speaker about a lexical item suggests that he or she has more lexical knowledge than the knowledge of word-specific idiosyncratic properties. The lexical knowledge is characterized with respect to verbs. All the grammatical information, that is, about tense, number, gender, etc is carried by the verbs in a sentence. These are the reasons why the study of verbs has acquired immense importance in Linguistics.
The work is based on the hypothesis of syntactic alternations. Syntactic alternations refer to the argument structure of the verbs. The work is guided by Beth Levin's work on syntactic alternations of English verbs. The basic assumption of Levin is that the behavior of a verb with respect to the expression and interpretation of its arguments is to a large extent determined by its meaning.

The motivation behind the work is to explore whether the verbs in the Indian languages can also be categorized semantically on the basis of this alternation pattern. At present, the work deals only with the syntactic patterns and does not handle the semantic classification.

\section{Alternations of English verbs}

The methodology of Levin is that the ideal lexical entry for a word should minimize the information provided for that word. According to her, this goal can be achieved by factoring predictable information out of lexical entries leaving idiosyncratic information. The principle behind this is that if the syntactic properties are followed from their meaning then it should be possible to identify general principles that derive the behavior of a verb from its meaning. This assumption gives rise to a powerful technique for investigating verb meaning that gives rise to the development of the theory of lexical knowledge. This states that if the behavior of the verb classes with respect to their alternations arises from their meaning then any class of verbs whose members pattern together with respect to their alternations should be semantically coherent class. After identifying such a class their members can be examined to isolate the meaning component they have in common [2]. Thus, alternation 
pattern plays an important role into the lexical representation of word meaning.

Levin had taken care of several types of alternations. Some instances of it are shown below:

\section{Middle alternation}

This is an intransitive alternation. The middle construction, that is, the intransitive variant of this alternation is characterized by a lack of time reference and by an understood but unexpressed agent.

1.a. The butcher cuts the meet.

b. The meet cuts easily.

\section{Dative alternation}

This type of alternation is characterized by an alternation between the prepositional frame 'NP1 V NP2 to NP3' and the double object frame 'NP1 V NP3 NP2'. The NP that is the object of the preposition to in the prepositional frame turns up as the first object in the double object construction.

2.a. Martha carved a toy for the baby.

b. Martha carved the baby a toy.

\section{Alternations in Indian languages}

Attempt has been made to see whether Indian languages also have the same sort of alternation as in English. The sample language that has been taken here is Hindi. The major differences that have been found between English and Hindi are that in case of English it is the same form of verb which is occurring in the alternation, but in Hindi the verb changes its form and hence, the morphological paradigm too. Levin's framework tends to be powerful for Indian languages also in a sense that it gives importance to the morphological properties along with the subcategorizational frame. This type of study is necessary because even a single property sometimes becomes sufficient to characterize a particular verb class. The examples of alternations occurring in Hindi are given in section 3.1 .

\subsection{Type of Alternation}

Transitivity Alternation. The transitivity alternations take the form of is 'NP V NP' alternating with 'NP V $(\mathrm{PP})^{\prime}(\mathrm{NP}=$ Noun Phrase, $\mathrm{V}=$ Verb, $\mathrm{P}=$ Preposition/ Postposition).

There are different types of alternations under the heading of this alternation.

Middle alternation. This type of alternations is found in Hindi with the pattern 'NP1 NP2 V' with 'NP PP V'. 3.a. The butcher cuts the meat.

b. The meat cuts easily.

Hindi: कसाई मांस काटता है।

यह मांस असानी से कटता है।

Causative / Inchoative alternation. This type

involves transitive and intransitive uses of verbs where the intransitive use of a verb $\mathrm{V}$ can be paraphrased as "cause to V-intransitive".

4.a. Janet broke the cup.

b. The cup broke.

Hindi: राम ने कप तोड़ा।

$$
\text { कप टूट गया। }
$$

Induced Action Alternation. This is also a type

of causative alternation which is found generally with the 'run' verbs. The causee is typically an animate volitional entity that is induced to act by the causer.

5.a. Sylvia jumped the horse over the fence.

b. The horse jumped over the fence.

Hindi: राम ने घोड़े को बाड़ के ऊपर से कुदवाया।

घोड़ा वाड़ के ऊपर से कूदा।

Substances/source alternation. This type of

alternation is found with verbs of substance emission. The alternating pattern is NP1 NP2 P V and NP2 NP1 V. The verb form also changes with the alternating pattern.

6 .a. Heat radiates from the sun.

b. The sun radiates heat.

Hindi: ताप सूरज से विकिरित होता है।

सूरज ताप विकिरण करता है।

Unspecified Object alternation. This alternation is characterized by wide range of activity verbs. The lack of direct object in the intransitive variant is understood to have as object something that qualifies as a typical object of the verb. The alternation variant is NP1 P NP2 V and NP1 P V.

7.a. Mike ate the cake.

b. Mike ate.

Hindi: राम ने केक खाया। राम ने खाया।

Understood body-part object alternation. This

alternation is found with verbs that describe certain gestures or signs made with the particular part of the body. In transitive use the verbs take this body part as their direct object and in intransitive use it is not taken but understood.

8.a. Jennifer craned her neck.

b. Jennifer craned.

Hindi: वह उचक के देख रहा था। वह गर्द्न ऊँची करके देख रहा था। 
In Hindi there is no single verb which show this type of actions. These are expressed by means of combination verbs, that is, by a combination of a noun and a verb.

Understood Reciprocal object alternation. The action denoted by the verb in the intransitive variant of this alternation can be roughly paraphrased by the transitive verb when it takes the reciprocal each other as object.

9.a. Anne met Cathy.

b. Anne and Cathy met.

Hindi: राम श्याम से मिला।

राम और श्याम मिले।

Syntactic pattern is NP1 NP2 V and NP1 and NP2 V.

Characteristic property of agent alternation.

Here both the variants indicate that the subject typically shows a propensity for the action named by the verb.

10.a. This dog bites people.

b. This dog bites.

Hindi: यह कुता लोगों को काटता है।

यह कुता काटता है।

The alternating syntactic pattern is NP1 NP2 P V and NP1 V.

Characteristic property of Instrument alternation. The intransitive variant of this alternation is used

to indicate an instrument's suitability for carrying out the action named by the verb.

11.a. I cut the bread with this knife.

b. This knife cuts the bread.

c. This knife doesn't cut.

Hindi: मैनें इस चाक से केक काटा।

इस चाकू से काटा जा सकता है।

इस चाकू से काटा नहीं जा सकता है।

This variant is found in Hindi.

Dative Alternation. This type of alternation is characterized by an alternation between the prepositional frame 'NP1 V NP2 to NP3' and the double object frame 'NP1 V NP3 NP2'. The NP that is the object of the preposition to in the prepositional frame turns up as the first object in the double object construction.

12.a. Bill sold a car.

b. Bill sold Tom a car.

Hindi: राम ने गाड़ी बेची।

राम श्याम को गाड़ी बेची।

The pattern alternates with NP1 P NP2 V and

NP1 NP2 P NP3 V.
Locative Alternation. These are verbs that relate to putting substances on surfaces or things in containers or to removing substances from surfaces or things from containers.

Spray/load alternation. This type of alternation is found with the transitive verbs.

13. a. Jack sprayed paint on the wall. (Locative variant)

b. Jack sprayed the wall with paint. (With variant)

Hindi: राम दीवार पर लाल रंग पोता।

राम ने लाल रंग से दीवार की रंगाई की।

Syntactic Pattern is NP1 NP2 locative NP3 V and NP1 P NP3 with NP2 V. The form of the verb also changes.

Clear alternation. This form of alternation is associated with the 'holistic/partitive' effect.

14.a. Clouds cleared the sky. (Locative variant)

b. The sky cleared.

Hindi: आसमान से वादल हट गये।

बादल हट गये।

Alternation Pattern is NP1 P NP2 V and NP2 V.

Material product alternation. This alternation is found with transitive verbs taking an agent argument expressed as subject and raw material and product arguments expressed within the verb phrase.

15.a. Martha carved a toy out of the piece of wood.

b. Martha carved the piece of wood into toy.

Hindi: राम ने इस लकड़ी के टुकड़े से खिलौना बनाया। राम ने इस लकड़ी के टुकड़े को खिलौने का रूप दिया।

Here, there is no change in the alternation pattern.

Simpler reciprocal agreement. This alternation involves verbs found in two frames in a near paraphrase relationship: 'NP1V [ ${ }_{p p}$ P NP2]' and '[ ${ }_{\mathrm{NP}} \mathrm{NP} 1$ and NP2] V'.

16.a. Brenda agreed with Molly.

b. Brenda and Molly agreed.

Hindi: राम श्याम से सहमत हुआ।

राम और श्याम सहमत हुए।

In Hindi the two frames for alternation are: 'NP1 NP2 [vP P V]' and '[ ${ }_{\mathrm{NP}} \mathrm{NP} 1$ and NP2] V'.

Fulfilling alternation. There is a superficial similarity with both the Dative and Locative variants. The alternating pattern here is 'NP V NP to NP' which is associated with dative alternation. The other variant of the alternation involves the frame 'NP V NP with NP' which is a locative alternation.

17.a. The Judge presented a prize to the winner. 
b. The Judge presented the winner with a prize.

Hindi: निर्णायक ने विजयी को पुरस्कार प्रदान किया। निर्णायक ने विजयी को पुरस्कार से सम्मानित किया।

In Hindi this alternation is not working as the frame for both the variants are 'NP case marker NP case marker NP V'

Together reciprocal alternation. This alternation involves verbs found in two frames in a near paraphrase relationship: 'NP1 V [PP P NP2]' and '[ ${ }_{\mathrm{NP}} \mathrm{NP1}$ and NP2] V'.

18.a. The eggs mixed with the cream.

b. The eggs and the cream mixed.

Hindi: अंडे के साथ क्रीम मिलाई गई है।

$$
\text { अंडे और क्रीम को मिलाया गया है। }
$$

The alternation pattern found in Hindi: '[NP NP1 P NP2] $\mathrm{V}$ ' and '[ $\mathrm{NP}_{\mathrm{NP}}$ 1 and NP2] V.

Possessor Subject (Transitive). This type of alternation is manifested by a set of transitive verb. This alternation involves the expression of a possessor and an attribute of the possessor.

19. a. The clown amused the children with his antics.

b.The clown's antics amused the children.

Hindi: जोकर ने अपने खेल से वच्चों के मन को वहलाया। जोकर ने बच्चों के मन को अपने खेल से वहलाया।

The alternation frame in Hindi is: '[ $\mathrm{NP}_{\mathrm{NP}} \mathrm{NP} 1$ case marker NP2 case marker NP3] V and '[ $\mathrm{NP}_{\mathrm{N}} \mathrm{NP} 1$ case marker NP3 case marker NP2] V'.

Possessor Subject (Intransitive). This is the intransitive

20.a. Meat fell in price.

b. The price of meat fell.

Hindi: सब्जी का भाव गिर गया।

भाव गिर गया सब्जी का।

Alternation Pattern is NP1 P NP2 V and NP2 V NP1.

Oblique Subject Alternations. Time Subject

alternation. 'Oblique' subjects of this type have been

characterized as 'natural forces'.

21.a. The world saw the beginning of a new era in 1492.

b. 1492 saw the beginning of a new era.

Hindi: पूरे विश्व ने 1492 में एक नये युग को शुरू होते देखा ।

1492 ने एक नये युग को शुरू होते देखा।

Two variants are NP1 P NP2 NP3 V and NP2 NP3 V.

Passive Alternation. This is a type of verbal passive. This type of passives generally occurs with the intransitive verbs.

22.a. The cook sliced the mushrooms.

b. The mushrooms were sliced by the cook.
Hindi: राम ने मशरूम काटी।

राम के द्वारा मशरूम काटी गई।

Passive alternations are found in Hindi though they are not very common in the language.

\subsection{Observations}

1. Not all the alternation does occur in Hindi but certain alternations of English do occur.

2.Unlike English in both the languages there is a phonological change in the verb form that changes the conjugation pattern and morphological paradigm.

3. In certain cases of alternation the verb form also occurs with the auxiliaries.

\section{Structure of verbs in Hindi}

From the observed data it was sure that in Indian languages it was not only the verb arguments that change but also the verbal form changes. In this connection it became obvious to put focus on the structure of the verbs.

Structurally Indian verbs are varied in nature. According to the structure we may get the following type of verbs [3]:

\section{Simple Verbs}

These verbs are made up of one single verb root. The entire transitive, intransitive and causative verbs fall under this group, for example, Hindi खाना सोना etc. The nominal verbs that are derived from either noun or adjective also fall under this group, for example, हथियाना, वतियाना etc.

\section{Conjunct Verbs}

These verbs are made up of different parts of speech along with a verb.These types of verbs are further classified into different categories according to different parts of speech. These types of verbs are more in number in Indian languages.

This type is further sub divided as:

Noun and Verb. This type is made up of a noun and a verb. Example for this type is आरंभ करना, दिखाई देना etc.

Adjective and verb. In this type the first part is an adjective while the second is the verb. Examples of such a type is मीठा लगना अच्छा लगना etc. 
Adverb and verb. Here the first component is an adverb and the last component is a verb. For example दूर हटाना धीरे चलना etc.

\section{Compound verbs}

This is a unique formation of verbs in Indian languages. There are verbs in Indian languages that are formed by a grammatical process more commonly known as compound formation or समास. Here, two verbs are subjected to the process of compounding. The typicality of this type lies in terms of meaning. This means that a verb $A$ meaning $x$ and a verb $B$ meaning $y$ when compounded together mean some thing other than $\mathrm{x}$ and $y$ but related to $x$ and $y$. For example, पढ़ना-लिखना means education but individually पढ़ना means to read and लिखना means to write. These types of examples are abundantly found in Indian language.

At present we have only concentrated on simple verbs to see what sort of phonological changes undergo that change the morphological paradigms of the verbs. The changes and the results of the changes are shown below:

\section{Morphological paradigms of Hindi verbs}

Traditional grammar books of Hindi classify several verbs under the simple verb category [4]. These are like nominal verbs that are verbs made out of nominal stems (Nouns, pronoun and Adjectives), transitive verbs, intransitive verbs and the causatives. Here, attempts have been made to group them linguistically. The work deals with the formation of the nominal verbs, intransitive-totransitive formation, and causative formations.

\subsection{Nominal Verbs}

These are verbs which are formed from nouns, pronouns or adjectives [5]. Nominal verbs are formed in different ways. The process of formation of this type of verbs is shown in table 1.1, 1.2 and 1.3.

Table 1.1. Nominal Verbs

\begin{tabular}{|l|l|l|l|}
\hline $\begin{array}{l}\text { Nominal } \\
\text { Root }\end{array}$ & Affix & $\begin{array}{l}\text { Nominal } \\
\text { stem }\end{array}$ & $\begin{array}{l}\text { Verb } \\
\text { form }\end{array}$ \\
\hline गर्म & आ & गर्मा & गर्माना \\
\hline शर्म & आ & शर्मा & शर्माना \\
\hline लाज & आ & लजा & लजाना \\
\hline दुख & आ & दुखा & दुखाना \\
\hline ठग & आ & ठगा & ठगाना \\
\hline नरम & आ & नरमा & नरमाना \\
\hline
\end{tabular}

\begin{tabular}{|l|l|l|l|}
\hline खटखट & आ & खटखटा & खटखटाना \\
\hline थरथर & आ & थरथरा & थरथराना \\
\hline भिनभिन & आ & भिनभिना & भिनभिनाना \\
\hline छनछन & आ & छनछना & छनछनाना \\
\hline टरटर & आ & टरटरा & टरटराना \\
\hline टिमटिम & आ & टिमटिमा & टिमटिमाना \\
\hline वड़वड़ & आ & बड़वड़ा & बड़वड़ाना \\
\hline हिनहिन & आ & हिनहिना & हिनहिनाना \\
\hline
\end{tabular}

The above process shows that if the monosyllabic nominal roots ending in closed syllable with consonants other than dental (in the pronunciation of which the tip of the tongue touches the upper front teeth) or retroflex (pronounced with the tip of the tongue turned back toward the hard palate) then first a vowel आ is added to convert it into stem. Then the verbal suffix -ना is added to form the verb. - ना is the verbal suffix of Hindi. In case of bisyllabic reduplicated roots, stem suffix आ is added to form a nominal stem if the roots end in any consonants.

Table 1.2. Nominal Verbs

\begin{tabular}{|l|l|l|l|}
\hline $\begin{array}{l}\text { Nominal } \\
\text { Root }\end{array}$ & Affix & $\begin{array}{l}\text { Nominal } \\
\text { stem }\end{array}$ & $\begin{array}{l}\text { Verb } \\
\text { form }\end{array}$ \\
\hline लात & इया & लतिया & लतियाना \\
\hline हाथ & इया & हथिया & जथियाना \\
\hline वात & इया & वतिया & वतियाना \\
\hline झूठ & ला & झुठला & झुठलाना \\
\hline
\end{tabular}

In the second process of nominal verb formation the stem suffix is - इया in case of roots ending in dental consonants and if it ends in retroflex sounds then the suffix is -ला. In this case, the root contains a long vowel which become short while converting into nominal stem.

Table 1.3. Nominal Verbs

\begin{tabular}{|l|l|}
\hline Nominal form & Verbal form \\
\hline फटकार & फटकारना \\
\hline ख़रीद & ख़रीदना \\
\hline अपना & अपनाना \\
\hline धिक्कार & धिक्कारना \\
\hline चिकना & चिकनाना \\
\hline मोटा & मुटाना \\
\hline
\end{tabular}

In the third process the verbal suffix - - r is added straightway to form verbal forms from bisyllabic closed syllable nominal form. If the nominal contains a long vowel it is shortened. 


\subsection{Intransitsive-causative formation}

This process deals with the formation of the causative verbs from the intransitive form. Two types of causations are found in Hindi. They are indicated in terms of degree. The hypothesis of first-degree causation is " $\mathrm{x}$ performs some action for $\mathrm{y}$ " and second-degree causation denotes " $x$ to make y perform some action for $z$ ". In case of intransitive -causative formation the first-degree causation is first transformed into a transitive form. To this transitive form then the suffix -वा is added to form second-degree causation. - वा is the suffix for seconddegree causation formation.

Table 2. 1 Intransitive-causative formation

\begin{tabular}{|l|l|l|}
\hline Intransitive & $\begin{array}{l}\text { Causative } \\
\left(\mathbf{1}^{\text {st }}\right. \\
\text { degree }) \\
\text { (Transitiv } \\
\text { e) }\end{array}$ & $\begin{array}{l}\text { Causative } \\
\left(\mathbf{2}^{\text {nd }} \text { degree }\right)\end{array}$ \\
\hline डरना & डराना & डरवाना \\
\hline गिरना & गिराना & गिरवाना \\
\hline चमकना & चमकाना & चमकवाना \\
\hline हँसना & हँसाना & हँसवाना \\
\hline चलना & चलाना & चलवाना \\
\hline बढ़ना & बढ़ाना & बढ़वाना \\
\hline ठहरना & ठहराना & ठहरवाना \\
\hline दौड़ना & दौड़ाना & दोड़वाना \\
\hline लड़ना & लड़ाना & लड़वाना \\
\hline चुभना & चुभाना & चुभवाना \\
\hline विगड़ना & विगाड़ना & विगड़वाना \\
\hline भींगना & भिंगाना & भिंगवाना \\
\hline भरना & भराना & भरवाना \\
\hline & & \\
\hline
\end{tabular}

The transformation of intransitive into transitive is done by various methods. These are discussed in table 2.1,2.2, 2.3, 2.4, and 2.5.

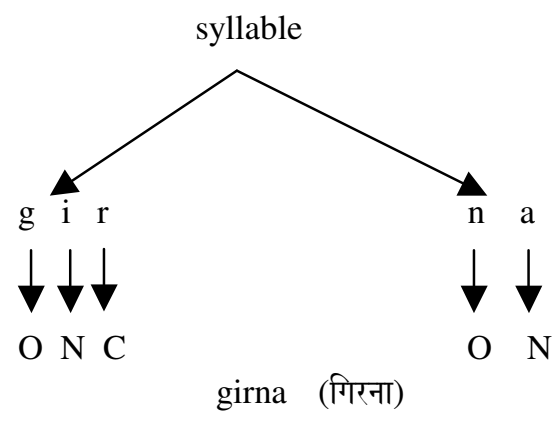

Figure 1.1 Syllable structure of गिरना.
The intransitive form has cvc-cv (where c stands for consonant and $\mathrm{v}$ for vowel) structure which is changed into a cvcvev structure. The syllable structure is shown in figure 1.1 .

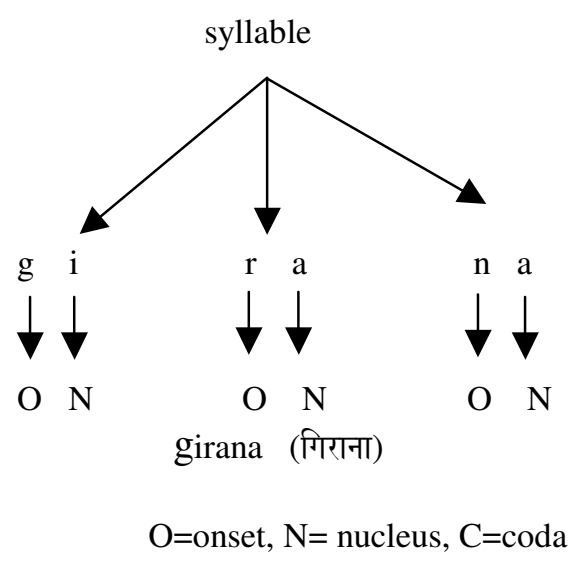

Figure 1.2 Syllable structure of गिराना.

Table 2.2 Intransitive-causative formation

\begin{tabular}{|l|l|l|}
\hline $\begin{array}{l}\text { Verb } \\
\text { (primary } \\
\text { form) }\end{array}$ & $\begin{array}{l}\text { Causative (1 } \\
\text { degree) }\end{array}$ & $\begin{array}{l}\text { Causative } \\
\left(2^{\text {nd }} \text { degree }\right)\end{array}$ \\
\hline सोना & सुलाना & शुलवाना \\
\hline रोना & रूलाना & रूलवाना \\
\hline खाना & खिलाना & खिलवाना \\
\hline
\end{tabular}

This is a case of dissimilation. Dissimilation is a process where one of the two similar sounds becomes dissimilar. Here, for the first-degree causation the suffix is -न. It becomes -ल in the context of -न in सोना. In this process of causation also the long vowel of the intransitive form becomes short in transitive form.

Table 2.3. Intransitive-causative formation

\begin{tabular}{|l|l|l|}
\hline $\begin{array}{l}\text { Verb } \\
\text { (primary } \\
\text { form) }\end{array}$ & $\begin{array}{l}\text { Causative (1 } \\
\text { degree) }\end{array}$ & $\begin{array}{l}\text { Causative } \\
\left(2^{\text {nd }} \text { degree }\right)\end{array}$ \\
\hline जाना & भेजना & भिजवाना \\
\hline
\end{tabular}

This is a case of suppletion.

Table 2.4. Intransitive-causative formation

\begin{tabular}{|l|l|l|}
\hline $\begin{array}{l}\text { Verb } \\
\text { (primary } \\
\text { form) }\end{array}$ & $\begin{array}{l}\text { Causative }\left(\mathbf{1}^{\text {st }}\right. \\
\text { degree) }\end{array}$ & $\begin{array}{l}\text { Causative } \\
\left(\mathbf{2}^{\text {nd }} \text { degree }\right)\end{array}$ \\
\hline लजाना & लज्जित करना & लज्जित करवाना \\
\hline नष्ट होना & नष्ट करना & नष्ट करवाना \\
\hline
\end{tabular}


To form causation auxiliaries are added to this type of verbs. -va- is added to the auxiliary in case of the $2^{\text {nd }}$ degree causation.

Table 2.5. Intransitive-causative formation

\begin{tabular}{|l|l|l|}
\hline $\begin{array}{l}\text { Verb } \\
\text { (primary } \\
\text { form) }\end{array}$ & $\begin{array}{l}\text { Causative (1 } \\
\text { degree) }\end{array}$ & $\begin{array}{l}\text { Causative } \\
\left(2^{\text {nd }} \text { degree }\right)\end{array}$ \\
\hline फटना & फाड़ना & फड़वाना \\
\hline जुड़ना & जोड़ना & जुड़वाना \\
\hline फूटना & फोड़ना & फुड़वाना \\
\hline टूटना & तोड़ना & तोड़वाना \\
\hline
\end{tabular}

To form $1^{\text {st }}$ degree causation vowel of the $1^{\text {st }}$ syllable is lengthened and the coda consonant of the $1^{\text {st }}$ syllable is changed into a flap voiced retroflex sound from a voiceless retroflex stop.

\section{3 Transitive-causative formation}

The third process involves the formation of causation from the transitive verbs. The process is somewhat similar to that of the intransitive version. Different instances of this process are given below:

Table 3.1. Transative-causative formation

\begin{tabular}{|l|l|l|}
\hline Transitive verb & $\begin{array}{l}\text { Causative }\left(\mathbf{1}^{\text {st }}\right. \\
\text { degree) }\end{array}$ & $\begin{array}{l}\text { Causative } \mathbf{2}^{\text {nd }} \\
\text { degree) }\end{array}$ \\
\hline पढ़ना & पढ़ाना & पढ़वाना \\
\hline लिखना & लिखाना & लिखवाना \\
\hline सुनना & सुनाना & सुनवाना \\
\hline लुटना & लुटाना & लुटवाना \\
\hline उठना & उठाना & उठवाना \\
\hline चलना & चलाना & चलवाना \\
\hline
\end{tabular}

The syllable structure of these forms is same with that of the transitive version, that is, cvc-cv. The first-degree causation is formed by changing the structure into cvevev where the nucleus of the second syllable consists a long vowel form. The syllable tree is shown in figure 2.1 .

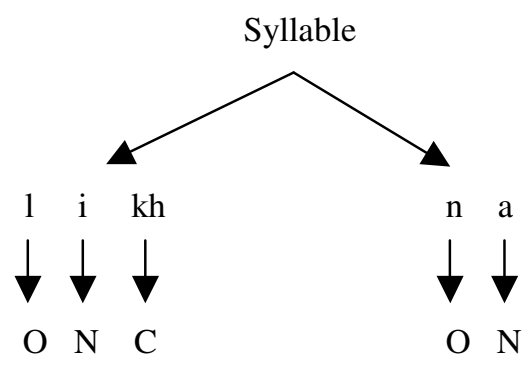

likhna (लिखना)

Figure 2.1 Syllable structure for लिखना.

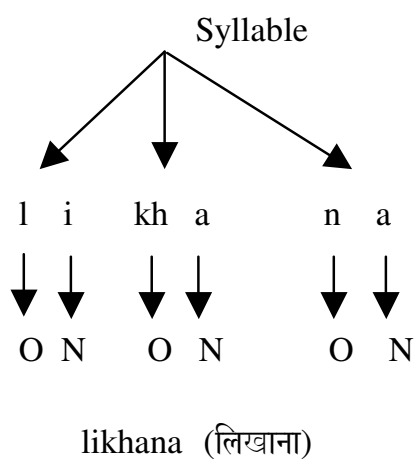

Figure 2.2 Syllable structure for लिखाना.

Table 3.2. Transitive-causative formation

\begin{tabular}{|l|l|l|}
\hline $\begin{array}{l}\text { Transitive } \\
\text { verb }\end{array}$ & $\begin{array}{l}\text { Causative }\left(\mathbf{1}^{\text {st }}\right. \\
\text { degree })\end{array}$ & $\begin{array}{l}\text { Causative } \\
\left(\mathbf{2}^{\text {nd }} \text { degree }\right)\end{array}$ \\
\hline जीतना & जिताना & जितवाना \\
\hline सीखना & सिखाना & सिखवाना \\
\hline काटना & कटाना & कटवाना \\
\hline बोलना & बुलाना & बुलवाना \\
\hline छोड़ना & छुड़ाना & छुड़वाना \\
\hline
\end{tabular}

This process shows similarity with the examples given in table 3.1 in the sense that it also changes the $\mathrm{crc}-\mathrm{cv}$ structure of the primary form into cvevev structure for forming first-degree causation. The long vowel of the primary form of the first syllable is shortened. The nucleus of the second syllable is a long vowel. The only difference is that it is a case of dissimilation like the one shown in table 2.2 .

Table 3.3. Transitive-causative formation

\begin{tabular}{|l|l|l|}
\hline $\begin{array}{l}\text { Transitive } \\
\text { verb }\end{array}$ & $\begin{array}{l}\text { Causative }\left(\mathbf{1}^{\text {st }}\right. \\
\text { degree})\end{array}$ & $\begin{array}{l}\text { Causative } \\
\left(\mathbf{2}^{\text {nd }} \text { degree }\right)\end{array}$ \\
\hline पीना & पिलाना & पिलवाना \\
\hline सीना & सिलाना & सिलवाना \\
\hline
\end{tabular}




\begin{tabular}{|l|l|l|}
\hline धोना & धुलाना & धुलवाना \\
\hline देना & दिलाना & दिलवाना \\
\hline खाना & खिलाना & खिलवाना \\
\hline
\end{tabular}

For this work, 300 verbs of Hindi are been investigated. The references of these verbs are taken from Hindi Wordnet [6]. In this paper only certain sample are shown.

\section{Conclusion}

In the present work, attempts have been made to deal with the verbs in detail with respect to their phonology, morphology and syntax. It is a challenging task for any kind of machine translation to deal with sentences of different syntactic pattern. So, the inclusion of the morphological paradigm and syntactic pattern of a language will be an obvious help for machine translation [7]. This information will be included in the lexicon wherever it will be relevant. Thus, given a frame like sprayed paint on the wall दीवार पर लाल रंग पोता and sprayed the wall with paint लाल रंग से दीवार की रंगाई की, one will able to extract the information that one variant occurs with the locative and the other with a post position.

The work will also be helpful in dealing with the phenomena of "language divergence" and "machine translation". The syntactic divergence is captured by means of rules in any process of analysis and generation from an interlingua [8]. Given a syntactic pattern for a language the task will become easier for the process of machine translation.

To capture the semantic nature of verbs this sort of analysis is necessary. The semantic categorization will provide with a deep hierarchy for the verbs. The deep hierarchical tree will provide insight into natural language processing, which, in turn will be useful for machine translation, building concept dictionaries etc. Thus, the next attempt of this work will be to utilize this information for creating semantic bases of verbs. Due to the shallow structure of the verb tree, machine translation faces problems in the disambiguation process. This semantic classification will help to handle the ambiguous nature of verbs.

\section{Acknowledgement:}

Prof. Milind S. Malshe and Prof. Vaijayanthi Sarma from the Department of Humanities and Social Sciences, IIT Bombay, have guided the work.

\section{References:}

[1]. Levin Beth, 1993, English Verb Classes and Alternations A Preliminary Investigation, The University of Chicago Press, Chicago.

[2]. Hale Kenneth, Keyser Samuel Jay, 1993, View from Building do, On Argument Structure and the Lexical Expression of Syntactic Relations, MIT Press.

[3].Bahari Hardev, 1997, Vyavaharik Hindi Vyakaran Tatha Rachna, Lokbharti Prakashan, Allahabad, India.

[4]. Singh Suraj Bhan, 1985, Hindi ka Vakyatmak Vyakaran, Sahitya Sahakar, Delhi, India.

[5]. Guru Kamata Prasad, Samvat 2058, Hindi Vyakaran, Nagari Pracharini Sabha, Varansi, India.

[6]. Chakrabarti Debasri, Narayan Dipak Kumar, Pandey Prabhakar, Bhattacharyya Pushpak, 2002, Experiences in Building the Indo Wordnet: A Wordnet for Hindi, Proceedings of the First Global Wordnet Conference.

[7]. Somers Harold L, Hutchins John W,1992, Introduction to machine translation, Academic Press,London.

[8]. Dave Shachi, Parikh Jignashu, Bhattacharyya Pushpak, 2002, Interlingua Based English Hindi Machine Translation and Language Divergence, Journal of Machine Translation, vol 17. 